\title{
THE ANALYSIS OF THE STRAIN INFLUENCE ON SOME YIELD ELEMNTS ON AN ASSORTMENT OF ISOGENIC WHEAT VARIETIES
}

\author{
PĂNIT⿱Ä Ovidiu \\ University of Craiova, Faculty of Agriculture and Horticulture, ovixfp@yahooo.com
}

\begin{abstract}
In the years 2012-2014 on Banu-Maracine DRS were tested an assortment consists of 25 isogenic lines of common wheat (Triticum aestivum ssp.vulgare), with the combination of Rht1 \& rht8 genes, the analyzed characters being the hight of the strain (cm), the number of seeds/spike, seeds weight/spike $(\mathrm{g})$, no. of spikes $/ \mathrm{m}^{2}$, weight of a thousand seeds (WTS) $(\mathrm{g})$ and no. of emerged plants $/ \mathrm{m}^{2}$. Based on recorded data and statistical processing of those, they were identified a numbers of links between these characters, links quantified by using the correlation.

Regarding the classification based on the average high of the strain, it was found that that there is a strong link between some characters too. Based on component analysis, the no. of seeds/spike and the seeds weight/spikes are components that influence in excess of $83 \%$ variance analysis, a total of five genotypes having positive scores for both factors.
\end{abstract}

Key words: Correlations, average values, principal component analysis

\section{Introduction}

The first cultivation of wheat occurred about 10000 years ago, as part of the 'Neolithic Revolution', which saw a transition from hunting and gathering of food to settled agriculture. These earliest cultivated forms were diploid (genome AA) (einkorn) and tetraploid (genome AABB) (emmer) wheats and their genetic relationships indicate that they originated from the south-eastern part of Turkey [3]. Cultivation spread to the Near East by about 9000 years ago when hexaploid bread wheat made its first appearance [5].

The genetic changes during domestication mean that modern wheats are unable to survive wild in competition with better adapted species. This was elegantly demonstrated by John Bennet Lawes in the 1880s when he decided to allow part of the famous long-term Broadbalk experiment at Rothamsted to return to its natural state [4].

The achievement of a genetic diversity by cultivating more genotypes with different reactions at the conditions of environment, with different precocity, constitutes the simplest way of reduction the fluctuation of the yield to plant crop [2].

Generally, the seeds are a good start for the future culture, if they have a high biological value, coming from improved genotypes with the genetic, physiological and morphological index of quality. From this point of view, a high mitotic activity is directly proportional to the genetic viability of the seed. Analysis of the mitotic activity and the mitotic division indexes can reveal the genotypic specificity and genetic diversity [1].

Regarding the phenomenon of dwarfing on wheat, genetic bases are determined by Rht genes type that is known to breeders for over 40 spikes and although it has been extensively used in wheat, this gene cannot be transferred on other cereals [8].

Worldwide, there are not yet fully known Rht genes effects that they have on the plant, but it seems that their actions are multiple, affecting more than plant height [9].

Varieties with high straw secure better sunlight, butt end to break under its own weight because of the fragility stem. Fertilization with nitrogen, vital in crop conditions on soils with low and very low fertility, cannot be applied in this situation, since the plants are breaking or semi-dwarf varieties have no longer problems regarding fertilization [7].

A number of projects worldwide are therefore focusing on understanding the processes that determine the efficiency of uptake, assimilation, and utilization of nitrogen in order to improve the efficiency of nitrogen recovery in the grain [6]. 


\section{Material and method}

In the years 2012-2014 on Banu-Maracine DRS were tested an assortment consists of 25 isogenic lines of common wheat (Triticum aestivum ssp. vulgare), with the combination of Rht1\&rht8 genes, the analyzed characters being the high of the strain $(\mathrm{cm})$, the number of seeds/spike, the seeds weight/spike (g), the no. of spikes $/ \mathrm{m}^{2}$, the weight of a thousand seeds (WTS) (g) and the no. of emerged plants $/ \mathrm{m}^{2}$. The links between characters were analyzed be using the correlations.

Regarding the interpretation of the correlation coefficient value, it was considered that when this is positive, the relationship between variables $\mathrm{X}$ and $\mathrm{Y}$ is "positive", namely an increase of $\mathrm{X}$ value character determines the overall growth of character $\mathrm{Y}$. When correlation coefficient value relationship between the two variables is "negative", an increase of $\mathrm{X}$ character generally has as a consequence a decrease of $\mathrm{Y}$ character. The interpretation of the correlation coefficient was applied according Colton (1974.). In our experiment there were consider that correlation which have a correlation coefficient value higher than +0.7

\section{RESULTS AND DISCUSSIONS}

Regarding the analyzed yield elements in Table 1 there is presented the variation of main parameters calculated. Thus, concerning the high of the strain, it had a value of $76.54 \mathrm{~cm}$ with a standard deviation of $6.71 \mathrm{~cm}$, the variation range between 65.7 and $90.7 \mathrm{~cm}$ respectively, and an amplitude of variation of $25 \mathrm{~cm}$.

Regarding the average no. of seeds/spike, it had a value of 22.7 seeds/spike with a standard deviation of 4.08 seeds/spike, limits of variation between 17.5 and 34.4 seeds/spike and an amplitude variation of 16.9 seeds/spike (Table 1).

Regarding the seeds weight/spike, the average was $0.98 \mathrm{~g}$ seeds/spike, with a standard deviation of $0.18 \mathrm{~g}$ seeds/spike, limits of variation between 0.70 and 1.57 seeds/spike and an amplitude variation of $0.87 \mathrm{~g}$ seeds/spike.

Regarding the no. of spikes $/ \mathrm{m}^{2}$, the average was $565.12 \mathrm{spikes} / \mathrm{m}^{2}$, with a standard deviation of 37.39 spikes $/ \mathrm{m}^{2}$, limits of variation between 500 and 614 spikes $/ \mathrm{m}^{2}$ and an amplitude of variation of 114 spikes $/ \mathrm{m}^{2}$.

Regarding the WTS, the average was $41.89 \mathrm{~g}$, with a standard deviation of $2.02 \mathrm{~g}$, limits of variation between 36 and $44.2 \mathrm{~g}$ and $8.2 \mathrm{~g}$ amplitude variation.

In the case of no. of emerged plants $/ \mathrm{m}^{2}$, the average was 351.48 emerged $\mathrm{pl} . / \mathrm{m}^{2}$, with a standard deviation of 32.33 emerged $\mathrm{pl} . / \mathrm{m}^{2}$, the variation range between 275 and 428 emerged $\mathrm{pl} . / \mathrm{m}^{2}$ and a variation amplitude of 153 emerged $\mathrm{pl} . / \mathrm{m}^{2}$.

Table 1: The variation of calculated parameters for the studied character

\begin{tabular}{|l|c|c|c|c|c|c|}
\hline Parameter & $\begin{array}{c}\text { The high of } \\
\text { the strain }(\mathrm{cm})\end{array}$ & $\begin{array}{c}\text { No of } \\
\text { seeds/spike }\end{array}$ & $\begin{array}{c}\text { Seeds } \\
\text { weight/spike }(\mathrm{g})\end{array}$ & $\begin{array}{c}\text { No. of } \\
\text { spike/m }\end{array}$ & $\begin{array}{c}\text { WTS } \\
(\mathrm{g})\end{array}$ & $\begin{array}{c}\text { No. of emerged } \\
\text { plants/m }\end{array}$ \\
\hline Average & 76.54 & 22.70 & 0.98 & 565.32 & 41.89 & 351.48 \\
\hline Range & $65.7-90.7$ & $17.5-34.4$ & $0.70-1.57$ & $\begin{array}{c}500- \\
614\end{array}$ & $\begin{array}{c}36.0- \\
44.2\end{array}$ & $275-428$ \\
\hline Variation amplitude & 25.00 & 16.90 & 0.87 & 114.00 & 8.20 & 153.00 \\
\hline Standard deviation & 6.71 & 4.08 & 0.18 & 37.39 & 2.02 & 32.33 \\
\hline $\begin{array}{l}\text { Variability } \\
\text { coefficient }\end{array}$ & 8.77 & 17.98 & 18.86 & 6.61 & 4.82 & 9.20 \\
\hline
\end{tabular}

In the present study, regarding the study on correlations between the studied characters, these are shown in Table 2. Thus, we identified strong links between:

- The no. of seeds/spike and seeds weight/spike, the correlation coefficient being of 0.838 .

- The no. of seeds/spike and the high of the strain, the correlation coefficient being equal with 0.806 .

- The seeds weight/spike and the high of the strain, the correlation coefficient being equal with 0.762 .

- The emerged plants $/ \mathrm{m}^{2}$ and no. of spikes $/ \mathrm{m}^{2}$, the correlation coefficient being of 0.762 . 
Table 2: The analysis of the correlation coefficients between the studied characters of whole experience

\begin{tabular}{lccccc}
\multicolumn{1}{c}{ Character } & $\begin{array}{c}\text { The high of } \\
\text { the strain }\end{array}$ & $\begin{array}{c}\text { No. of } \\
\text { seeds/spike }\end{array}$ & $\begin{array}{c}\text { Seeds } \\
\text { weight/spike }\end{array}$ & $\begin{array}{c}\text { No. of } \\
\text { spike/m }\end{array}$ & WTS \\
\hline No. of seeds/spike & $\mathbf{0 . 8 0 6}$ & - & - & - & - \\
\hline Seeds weight/spike & $\mathbf{0 . 7 5 6}$ & $\mathbf{0 . 8 3 8}$ & - & - & - \\
\hline No. of spike/m ${ }^{2}$ & 0.092 & 0.278 & 0.161 & - & - \\
\hline WTS & -0.632 & -0.635 & -0.607 & -0.254 & \\
\hline No. of emerged $\mathrm{pl} . / \mathrm{m}^{2}$ & -0.206 & 0.021 & -0.172 & $\mathbf{0 . 7 6 2}$ & 0.063
\end{tabular}

Subsequently, the studied genotypes were grouped according to the high of the strain average in two categories namely:

- Genotypes with the high of the strain value lower than the average, the number of those ones being of 14 lines

- Genotypes with the high of the strain value higher than the average, the number of those ones being of 11 lines

For these two groups were also calculated correlation coefficients using the method applied to the whole group (Table 3).

Thus, in the case of the genotype having a size below the average, there were three links, namely: the no. of seeds/spike and the high of the strain, the correlation coefficient being 0.737; the high of the strain and seeds weight/spike, the correlation coefficient being 0.764 ; the no. of emerged plants $/ \mathrm{m}^{2}$ and the no. of spikes $/ \mathrm{m}^{2}$, the correlation coefficient being 0.776 .

Table 3: The analysis of the correlation coefficients between the studied characters of the genotypes with the high of the strain under the average

\begin{tabular}{lccccc}
\multicolumn{1}{c}{ Character } & $\begin{array}{c}\text { The high of } \\
\text { the strain }\end{array}$ & $\begin{array}{c}\text { No. of } \\
\text { seeds/spike }\end{array}$ & $\begin{array}{c}\text { Seeds } \\
\text { weight/spike }\end{array}$ & $\begin{array}{c}\text { No. of } \\
\text { spike/m }\end{array}$ & WTS \\
\hline No. of seeds/spike & $\mathbf{0 . 7 3 7}$ & - & - & - & - \\
\hline Seeds weight/spike & 0.348 & $\mathbf{0 . 7 6 4}$ & - & - & - \\
\hline No. of spike/m ${ }^{2}$ & -0.025 & 0.287 & 0.082 & - & - \\
\hline WTS & -0.453 & -0.471 & -0.317 & -0.291 & - \\
\hline No. of emerged $\mathrm{pl} . / \mathrm{m}^{2}$ & -0.037 & 0.103 & -0.195 & $\mathbf{0 . 7 7 6}$ & -0.252
\end{tabular}

In the case of the genotype having the high of the strain higher than the average, there were four strong links, namely (table 4):

- the no. of seeds/spike and the high of the strain, the correlation coefficient being 0.834 .

- the high of the strain and the seeds weight/spike, the correlation coefficient being 0.780 .

- the no. of emerged plants $/ \mathrm{m}^{2}$ and the no. of spikes $/ \mathrm{m}^{2}$, the correlation coefficient being

0.837 .

- the no. of seeds/spike and the seeds weight/spike, the correlation coefficient being 0.780 .

Table 4: The analysis of the correlation coefficients between the studied characters of the genotypes with the high of the strain higher than the average

\begin{tabular}{lccccc}
\multicolumn{1}{c}{ Character } & $\begin{array}{c}\text { The high of } \\
\text { the strain }\end{array}$ & $\begin{array}{c}\text { No. of } \\
\text { seeds/spike }\end{array}$ & $\begin{array}{c}\text { Seeds } \\
\text { weight/spike }\end{array}$ & $\begin{array}{c}\text { No. of } \\
\text { spike/m }\end{array}$ & WTS \\
\hline No. of seeds/spike & $\mathbf{0 . 8 3 4}$ & - & - & - & - \\
\hline Seeds weight/spike & $\mathbf{0 . 7 8 0}$ & $\mathbf{0 . 7 9 0}$ & - & - & - \\
\hline No. of spike $/ \mathrm{m}^{2}$ & -0.047 & 0.211 & 0.109 & - & - \\
\hline WTS & -0.522 & -0.561 & -0.553 & -0.165 & - \\
\hline No. of emerged $\mathrm{pl} / \mathrm{m}^{2}$ & -0.175 & 0.141 & -0.032 & $\mathbf{0 . 8 3 7}$ & 0.149
\end{tabular}

Based on comparative analysis of the calculated correlation coefficients for both the whole experience and for genotypes ranked according with the high of the strain average, it can be assumed that in the case of genotypes higher than the high of the strain average, the coefficient correlation increases, while for genotypes with the high of the strain below average, the correlation coefficient decreases (Chart 1). 


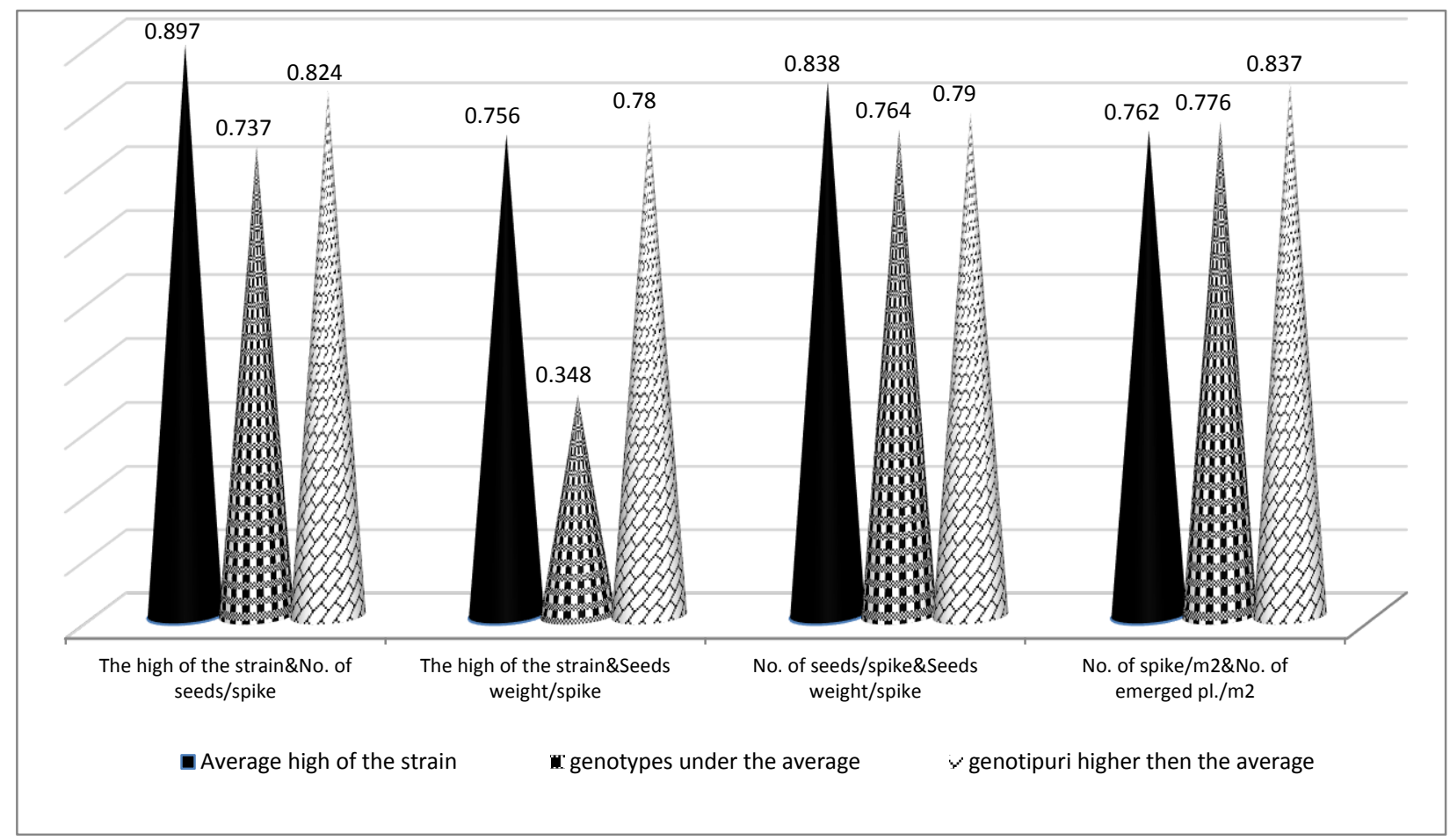

Chart 1- The variation of the correlation coefficients depending on the classification of the analyzed genotypes

Thus, regarding the correlation between the high of the strain and the no. of seeds/ spike, on the entire experiment we calculated a correlation coefficient of 0.829 , while on the genotypes above average the coefficient was by 0.824 , and on genotypes under average it was calculated a coefficient equal to 0.737 . In other words, we can say that, regardless of size, it can be said that there is a strong link between these two characters.

Regarding the analysis of the correlation between the no. of seeds/spike and seeds weight/spike, on the entire experiment it was calculated a correlation coefficient of 0.838 , while on genotypes above average it was calculated a coefficient of 0.79 , and for genotypes below the average it was calculated a coefficient equal to 0.764 . In other words, we can say that, regardless of size, it can be said that there is a strong link between these two characters.

Regarding the analysis of the correlation between the high of the strain and the seeds weight/spike, on the entire experiment it was calculated a correlation coefficient of 0.756 , while on genotypes above the average the coefficient was by 0.834 , and on genotypes with a value below the average it was calculated a coefficient equal to 0.348 . In the analysis of the link between these characters, we can say that for this type of isogenic lines the seeds weight/spike increases with increasing the high of the strain and decreases with decreasing it.

Regarding the analysis of the correlation between the no. of the emerged plants $/ \mathrm{m}^{2}$ and the no. of spikes $/ \mathrm{m}^{2}$ on the whole experiment it was calculated a correlation coefficient of 0.762 , while on genotypes above the average the coefficient was 0.837 and on the genotypes under the average value it was calculated a coefficient of 0.776 . In other words, we can say that, regardless of size of the strain, it can be said that there is a strong link between these two characters.

In the present study it was carried out and principal components analysis (PCA). Thus the first two factors, namely no. of seeds/spike and seeds weight/spike influenced the variance to an extent of $83.38 \%$ (Table 5).

In this analysis, based on two components that scored the highest, there were identified the following groups (Chart 2):

- Group I with six genotypes, in which both components have positive scores

- Group II with four genotypes, the first component has positive values and the second component is negative

- Group III genotypes having five, where in both components have negative scores

- Group IV genotypes having ten, where the first component is negative and the second component is positive. 
Table 5: Eigenvalues and component score coefficients

\begin{tabular}{|c|c|c|c|c|c|}
\hline \multirow{2}{*}{\begin{tabular}{c} 
Component \\
\cline { 2 - 6 }
\end{tabular}} & \multicolumn{3}{|c|}{ Initial Eigenvalues } & \multicolumn{2}{c|}{$\begin{array}{c}\text { Component Score } \\
\text { Coefficient Matrix }\end{array}$} \\
\cline { 2 - 6 } & Total & $\%$ of Variance & Cumulative \% & 1 & 2 \\
\hline No. of seeds/spike & 3.218 & 53.626 & 53.626 & 0.286 & 0.056 \\
\hline Seeds weight/spike & 1.786 & 29.759 & 83.385 & 0.285 & -0.042 \\
\hline No. of spike/m ${ }^{2}$ & 0.458 & 7.626 & 91.011 & 0.045 & 0.515 \\
\hline WTS & 0.245 & 4.086 & 95.097 & -0.248 & -0.036 \\
\hline No. of emerged plants/m ${ }^{2}$ & 0.187 & 3.112 & 98.209 & -0.068 & 0.531 \\
\hline The high of the strain & 0.107 & 1.791 & 100.000 & 0.286 & -0.076 \\
\hline
\end{tabular}

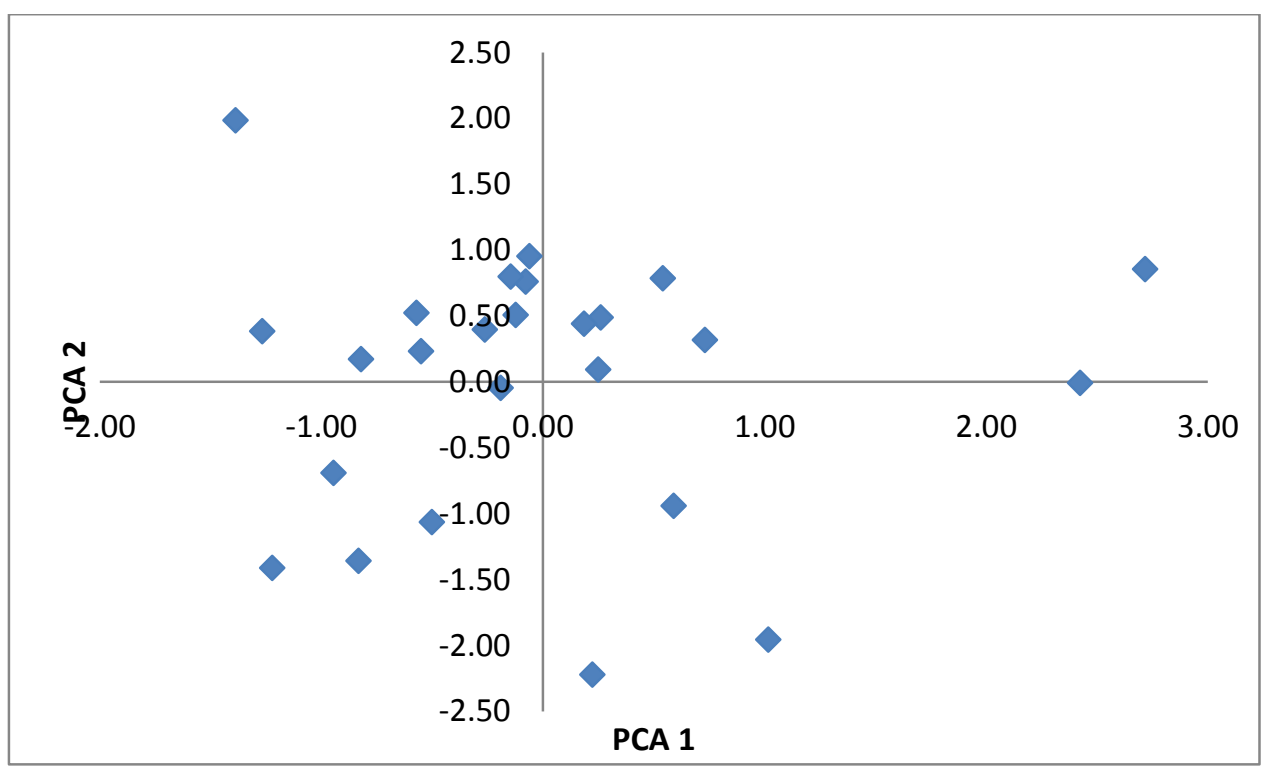

Chart 2 - The chart of two main components, the no. of seeds/spike and the seeds weight/spike

\section{Conclusions}

Based on recorded data and statistical processing of it, it can draw the following conclusions:

1. Strong links were found between the no. of seeds/spike and the seeds weight/spike, between the no. of seeds/spike and the high of the strain, between seeds weight/spike and the high of the strain and between the no. of emerged plants $/ \mathrm{m}^{2}$ and the no. of spikes $/ \mathrm{m}^{2}$.

2. On the classification based on the average high of the strain of the genotypes, it was found that on the analysis of the link between the no. of seeds/spike and the seeds weight/spike, regardless of variability waist, it can be said that there is a strong link between these two characters, same situation being on the analysis of the link between the no. of seeds/spike and the seeds weight/spike.

3. Based on the analysis of components, no. of seeds/spike and seeds weight/spike are components that influence in excess of $83 \%$ variance analysis, a total of seven genotypes having positive scores for both factors.

\section{Acknowledgments}

This work was supported by the strategic grant POSDRU/159/1.5/S/133255, Project ID 133255 (2014), coffinanced by the European Social Fund within the Sectorial Operational Program Human Resources Development 2007-2013. 


\section{References}

1. Bonciu, E., Variability of the mitotic activity to some foreign sunflower genotypes. Journal of Horticulture, Forestry and Biotechnology, Volume 17(3), p. 126-129. Editura Agroprint, Timişoara, (2013).

2. Bonciu, E., Iancu, P., Soare, M., Researches concerning some foreign sunflower genotypes behavior under the condition of red preluvosoil from the central area of Oltenia. Scientific Conference with international participation "Durable Agriculturte-Agriculture of future" the sixth edition and "The National Mycology Symposium", the XXII ${ }^{\text {nd }}$ Edition. Vol. XL/2 2010. p. 39-43, ISSN 1841-8317. Editura Universitaria, Craiova, (2010).

3. Dubcovsky, J., Dvorak J., . Genome plasticity a key factor in the success of polyploidy wheat under domestication. Science;316:1862-1866, (2007).

4. Dyke, G.V. John Lawes of Rothamsted. Pioneer of science farming and industry. Harpenden, UK: Hoos Press; (1993).

5. Feldman M. Origin of cultivated wheat. In: Bonjean AP, Angus WJ, editors. The world wheat book: a history of wheat breeding. Paris, France: Lavoisier Publishing;. p. 3-56. (2001)

6. Foulkes MJ, Hawkesford MJ, Holdsworth M, Kerr S, Kightly S, Shewry PR. Identifying traits to improve the nitrogen economy of wheat: recent advances and future prospects. Field Crops Research (2009). (in press).

7. Păunescu, G. - Codul decimal pentru stadiile de vegetație la grâu. Ed. Sitech, Craiova (2007).

8. Soare, M. Ameliorarea plantelor agricole. Partea specială. Editura Universitaria. Craiova, (2004).

9. Voica, N., Soare, M., Soare, P., Genetica vegetală. Editura Universitaria, Craiova (2004) 